\title{
Rebranding as an Elementary Part of Corporate Repositioning and Reputation Management - Addiko Bank Example
}

Original scientific paper _ DOI 10.22522/cmr20170221 _ received on 22 August 2017 UDK 005.57:005.6

\section{Igor Vukasović}

Addiko Bank, Croatia. Email: i.vukasovic@gmail.com (corresponding author)

\section{Iva Ančić}

Addiko Bank, Croatia. Email: iva.ancic1@gmail.com

\section{Dora Starčević}

Edward Bernays College of Communication Management (student),Croatia. Email: dora.starcevic@yahoo.ie

........

\section{Abstract}

Reputation and brand are two of the most important, if not the most important, corporate assets which play a significant role in the company' success or demise. Brands have an ability to impact people's perception and hence managing the brand and the reputation is more, much more than just having an interesting name, memorable slogan or recognizable logo. It's about being loyal to its corporate values and remaining relevant to its customers. With the rebranding marking a fundamental change for the corporation, both in terms how it does business also how it communicates, this paper focuses on the rebranding of the former Hypo Alpe-Adria-Bank into Addiko Bank, with the new brand, being an elementary part of the business strategy. The aim of the paper is to show by developing a compelling new brand a bank burdened by past image can reposition itself and again become a viable contender. In order to get the full insight, focus groups, interviews and workshops with Bank's management, employees and clients were conducted. Based on the research results, the new brand was created and launched with successful rebranding having a positive impact on not only corporate repositioning and reputation, but also on financial results in 2016 and 2017.

Keywords: brand, rebranding, repositioning, image, banking, reputation management 


\section{Methodology}

Following the 2015 privatization, with the new ownership structure of global active private equity investor and the European Bank for Reconstruction and Development in place, and in line with the new business strategy, Addiko Group ${ }^{1}$ decided to start future business operations under the new Addiko brand. In order to decide which direction Addiko Bank needed to take in terms of brand positioning, brand vales and brand reputation, detailed analyses and several levels of research were conducted.

Since the Bank, at the end of 2015, was still Hypo Alpe-Adria-Bank, and at that time of initiating the rebranding process did not have any recent relevant research, in order to evaluate the current brand position and reputation situation a Financial market data survey (FMDS) $)^{2}$ was used as "ground zero". The said research encompassing 1000 participants was conducted in four waves during 2014, with the main focus being on evaluating the current situation at that time in the Croatian banking sector in terms of brand, satisfaction, products and services.

After analysing the FMDS research results that served as a solid foundation and with the goal of obtaining comprehensive insight, in the following research phase an additional internal and external research was conducted. Data was collected via in-depth interviews with 40 participants, aged 30 to 55 divided into two groups: employees and clients. The client sample consisted of representatives of each banking sector: regular retail clients, retail VIP clients, corporate and SME clients. The employee sample consisted of representatives from all business segments; Management Board members, executive directors, business development managers, corporate and SME financial advisers, branch managers, sellers and tellers, as well as call centre employees. Also, several workshops with the Bank's management were conducted in order to define in more detail the areas where improvements needed to be made.

The next research phase, a detailed analysis of the previous research stage results, took place with key findings used to define the new business, communication and creative

1 An international financial group headquartered in Vienna, Austria, operating through six banks with its core business in Croatia, Slovenia, Bosnia and Herzegovina, Serbia and Montenegro, providing banking services to over 1 million customers.

2 Survey conducted by a market research institute Gesellschaft für Konsumforschung (GfK). 
strategy. The main theses were then tested externally through organized focus groups.

Based on all these research results, the new Addiko brand was created and launched on 11 July 2016. Then followed the brand tracking phase, which took place in three waves: the first in October 2016, the second in February 2017, and the third in May 2017, and which was undertaken to ensure accurate monitoring, measuring and evaluation of the impact the new Addiko brand had on the Bank's positioning and its reputation within the target audience. The brand tracking was done by means of an online questionnaire with a representative sample of 500 participants according to age (in terms of Addiko Bank's target audience).

The Statistical Package for the Social Sciences (SPSS) was used for brand tracking data analysis with tests of significance used. Depending on the questions, i.e. for comparison of research waves calculations for independent sources were used. For differences between individual answers, a mutually exclusive classification calculation was used for questions with one answer possible, while an overlapping classification was used for questions that had more than one possible answer. All the research was conducted in the period from October 2016 to May 2017.

\section{Identity, Image, (Re)Brand and Trust}

Despite the fact that the two are related concepts, they are not the same, very frequently "identity" is confused with "image”, or as John M. Murphy (1987, p. 158) explains it - "An image is the perception that the public has of a company. It is the cumulative result of many different influences such as quality of products and management, price range, advertising style, status in the community - and permanent media. An image exists in the public's mind. Identity, on the other hand, is the objective reality. It is the corporation as it actually exists in the real world."

The reality for Hypo Alpe-Adria-Bank was that, due to reputation issues, the consumers' consideration of Hypo was not at a desired level and hence affected the bank's business performance and more importantly burdened future and new business; and this regardless 
of the new ownership. This was the rationale behind the idea of the rebranding - providing the new Addiko Bank with a fresh start, a blank slate if you will, and an opportunity to make a new impression not inhibited by the past, with the new brand as the symbol of the positive change and transformation.

According to Larry Light and Joan Kiddon (2016, p. 156) "there are more than 100 different definitions of the word brand" with it being one of the most used and misused terms today. This is due to the fact that a brand is the perceived added value that a company or product represents, making customers increasingly loyal in preferences both to the company and to its products (Fog, Budtz et al., 2001, p. 22). In terms of the broader business-social impact of a brand, Sylvia M. Chan-Olmsted (2006) concludes that "the brand image should ideally be a unique set of positive associations comprising the values and promise of the brand, with these associations ultimately transforming into a positive attitude towards the brand, a higher purchase probability and continued brand loyalty" (as cited in Siegert, Förster, Chan-Olmsted, 2015, p. 67).

\subsection{Importance of Internal Stakeholders}

A study conducted by Dixon-James Communications (2015) among 32 organizations across all industry sectors that were rebranded during the past two year showed that, while there are multiple reasons for rebranding, the study participants ranked the primary reasons for rebranding in the following order: (a) creating opportunity for growth; (b) prior brand was no longer relevant; (c) sale of company/new leadership; (d) competitive pressures. The study concludes that rebranding efforts can face many obstacles to their success, but that actually it is the matter of gaining internal alignment around the new brand platform that presents the biggest challenge.

Mary Jo Hatch and Majken Schultz (2008, p. 229) confirm this by stating "putting your brand behind your employees may be the single most important thing you can do, because only when your employees blend corporate brand thinking into their everyday work practices will customers experience the significance of your brand in their lives”. Only then does the organization cross the long and widening road from good to great, from average to 
desirable to work for and with. John Mattone and Nick Vaidya (2016) add to this argument by stating that it is their position that real sustainable transformation requires new mind-sets, not just new skills, with Light and Kiddon (2016, p. 108) adding that "to gain favouritism (internal and external), it is necessary to change people's attitudes about that brand, with attitude representing an accumulation of information".

British advertising expert Jeremy Bullmore said "People build brands as birds build nests, from scraps and straws we chance upon. The applicability to brands is that, while a corporation may own and try to control the image, it cannot to full control the content of associations customers make" (as cited in Ind, 2003, p. 23). Jeff Bezos's statement that "your brand is what other people say about you when you're not in the room" has been often quoted, but still the fact remains that building a brand starts from within. It is not a one-off event but a continuous process over a long period of time. This is why the internal element and motivating employee engagement is a crucial part of the rebranding transformation, with the brand identity inevitably transcending to brand image.

\section{2. (Re)Evolution of a Brand as a Major Credibility Factor}

Nicholas Ind (2003) also argues that over the past 100 or so years, the term "brand" has undergone a radical evolution from commodity, to product, to experience, to relationship, to the interdependent living system of stakeholders, and that it can be viewed as the sum total of relationships among stakeholders, but not just for the stakeholder class we call “consumers”. According to Light and Kiddon (2016, p. 12), “properly managing brands

means managing for continuing success, taking the brand to the next level, because brands can live forever if they are properly managed".

Still, in this particular case, rebranding was one of the key strategic projects for the Addiko Bank in 2016, and one that to a great extent determined the Bank's future. Facing headlines like the ones in Wall Street Journal "Hypo Alpe-Adria-Bank Mess" (Steinhauser, 2014), or Reuters's "Decline and Fall of Hypo Alpe Adria, Symbol of Austria's Balkan Ambitions" (Gruber, Nasralla, 2015) was a clear and strong signal that despite the aforementioned articles reflecting on the pre-2009 nationalization matters and the Bank having no issues 
connected to it since 2009, it needed a change.

Gabriele Siegert, Kati Förster and Sylvia M. Chan-Olmsted (2015, p. 164) explain "branding is a strategy of differentiation and companies use branding to differentiate themselves from competitors who offer almost the same products with limited quality difference, with the brands meant to convey reliability and continuity”. In Addiko's core South-Eastern Europe markets, the market situation was very competitive and saturated, with over 25 commercial banks operating in some markets and offering a similar portfolio of services, which did not differentiate much in terms of pricing.

Although companies are usually reluctant to change a brand's most visible communication instruments, their name and logo, because these keep the brand recognizable (Siegert, Förster, Chan-Olmsted, 2015), also pointed out are that there are circumstances under which a modification makes sense. The need for rebranding can occur when companies are either unsuccessful in establishing one brand, or in cases when a brand had experienced reputational issues with the intention of rebranding then being to erase the previous image and to establish a fresh one. The launch of a new Addiko brand was a necessity for the Bank and hence logically an essential part of its business strategy. The goal of Addiko's rebranding was according to the Bank's CMO for Retail Razvan Munteanu (2015, para 4, 5) "to create a credible, relevant and distinctive new brand that encompasses the Bank's straightforward corporate and business values, with the business strategy directly linked and aligned with the new brand, as its driving force for moving away from an undesirable perception of the past, and increasing consumer considerations, which should lead to building trust and generating business growth".

Generally many consider rebranding as a cosmetic activity as cited in Rita Clifton (2009, p. 9). "If branding is treated as a cosmetic exercise only, and regarded merely as a new name, logo, advertising campaign, it will have only a superficial effect at best. If this cosmetic approach is applied in an effort to make a bad or confused business look more attractive, it is easy to see why these so-called rebranding exercises encourage such cynicism. Reputation is, after all, reality with a lag effect." With also Ind (2003) adding that unfortunately too many organizations go through the motions of a (re)branding exercise without living it, which results in the inability for a brand to live up to the expectations and puts a big dent in its reputation. 
Under the aegis of brand management in terms of customer-centricity, Light and Kiddon (2016) argue that relevance, which along with differentiation is necessary for defining brand value, means the brand is up to date and current in customers' minds as it addresses the current customer needs. According to Light and Kiddon (2016, p. 155) "a powerful brand is more than a trademark; it is a trustmark with trust being the most important prerequisite for building long-term brand loyalty, as it facilitates persuasion and the acceptance of new information". With trust being a cherished asset that one has to deserve by doing right things, the right way over a longer period of time, building a positive image of Addiko, a completely new banking brand without any backing or heritage of an internationally renowned banking group, was especially important.

\section{Reputation - a Coveted Asset}

“Reputation, reputation, reputation! O! I have lost my reputation, I have lost the immortal part of myself, and what remains is bestial." I honestly doubt that in 1604 when William Shakespeare wrote about reputation in his tragedy Othello he thought his words would be quoted in corporate contexts. Nevertheless, the intangible asset that is reputation has since, and especially in today's increasingly globally competitive world of business and a constantly changing landscape, grown in importance and become one of the key differentiators customers are looking for when picking a partner.

John Roberts (2004, p. 161) defines reputational capital as "the difference between the book value of an organization and its market value”, adding that it is built on the trust and confidence of stakeholders in an organization that it will act in their best interests, and for a reputation to be effective, in each interaction between the organization and its key stakeholders (customers, employees, suppliers, etc.).

Charles J. Fombrun and Violina P. Rindova (1996) identify corporate reputation along five dimensions, concluding that reputations are: (a) historically rooted; (b) of concern to internal and to external stakeholders; (c) based on past actions and achievement; (d) assessed on the benefits accrued by individual stakeholder groups; and (e) used to position the company in terms of both its competitors and its business environment (Balmer, Greyser, 
2003, p. 225). Charles J. Fombrun and Cees B.M. van Riel (1998) also state that consumers rely on a company's reputation because they have less information than managers do about a company's commitment to delivering desirable product features like quality or reliability (Balmer, Greyser, 2003, p. 225).

\subsection{Reputation Does Make the Difference}

Margulies confirms the importance of corporate reputation by concluding that in order to create a positive image and, over time, a positive reputation, a company must successfully communicate and manage the way it wishes to be viewed by key stakeholder groups (Balmer, Greyser, 2003, p. 66). John M. T. Balmer and Edmund R. Gray (1999) argue that companies with high visibility and strong reputations have a competitive advantage in fluid markets because their respected names add value to their products by reducing uncertainty in the minds of their customers, retailers and distributors (Balmer, Greyser, 2003, p. 127). Siegert, Förster and Chan-Olmsted (2015) weigh by stating that the brand culture should be understood as a strategic asset, while Mattone and Vaidya (2016, p. 2) conclude that "the organization's culture represents the collective character, thoughts, emotions, beliefs, and behaviours of its leaders and individual contributors, which is then reflected in the creation and implementation of the organization's values, vision, mission, purpose, strategy, structure, and roles”.

But how does one position and market a completely new brand whose owners do not have commercial banking credentials? And this in very saturated banking markets with over 25 competitors, some of which have been operating for over 100 years. How does one generate growth in markets that experienced six years of recession and 5-year-long lending decline, where the banks have been plagued by criticism for past lending and the business focus is on Retail and SME services that every other competitor bank is also offering? By acknowledging customer needs and delivering on the brand promises that are synced with customer demands and perception of what their bank of choice should be. Or as Klaus Fog, Christian Budtz and others put it (2001, p. 186): “It's not about the brand itself. It's about the social function that the story of the brand achieves in the dialogue between people. It's 
no longer just about telling stories. It's about listening and finding your role in a dialogue where your consumers are the directors." According to a News Positioning and Evaluation of the RTB's customer research conducted by the market research company Ipsos in 2016, the lack of transparency has been identified as one of the main customer objections to banks. The undertaken research and workshops also uncovered a crucial customer insight that customers felt confused by overly complex banking products, piles of paperwork, with customers essentially wanting a simpler, hassle-free way of banking. This led to Addiko's developing its brand promise of straightforward banking, which according to the Bank's website stands for focusing on essentials, delivering on efficiency and communicating more simply. Balmer and Gray (1999, as cited in Balmer, Greyser, 2003, p. 127) conclude that corporate communications is an essential part of a company's repositioning efforts as it forms a tripartite bridge between an organization's identity and the resulting image and reputation.

\section{Research}

\subsection{Financial Market Data Research - FMDS 2014}

The PAPI Method Omnibus (Paper-and-Pen-Interview, the so called Face-to-Face method) was used for this research on the population of Croatia aged 15+, and was conducted on a sample of 1000 respondents, while the fieldwork was done in four waves spanning from March, June and September to December 2014. The key findings of this research in terms of monitoring the development and trends of brand awareness showed that the Hypo brand was affected by constant pressure due to substantial negative media coverage and lack of regular mass media campaigns. Client share remained more or less steady and stable. However, the gap between acquired new clients and those who left/reduced their relationship with Hypo showed a negative gap of 0.02 (new clients 0.35 vs. lost clients 0.37). Even though respondent satisfaction with the main bank in general was overall low (the average score was 4.23) as seen on the figure below, the score for Hypo was even lower (4.07), with Splitska banka (3.85) being the bank with the lowest score. 


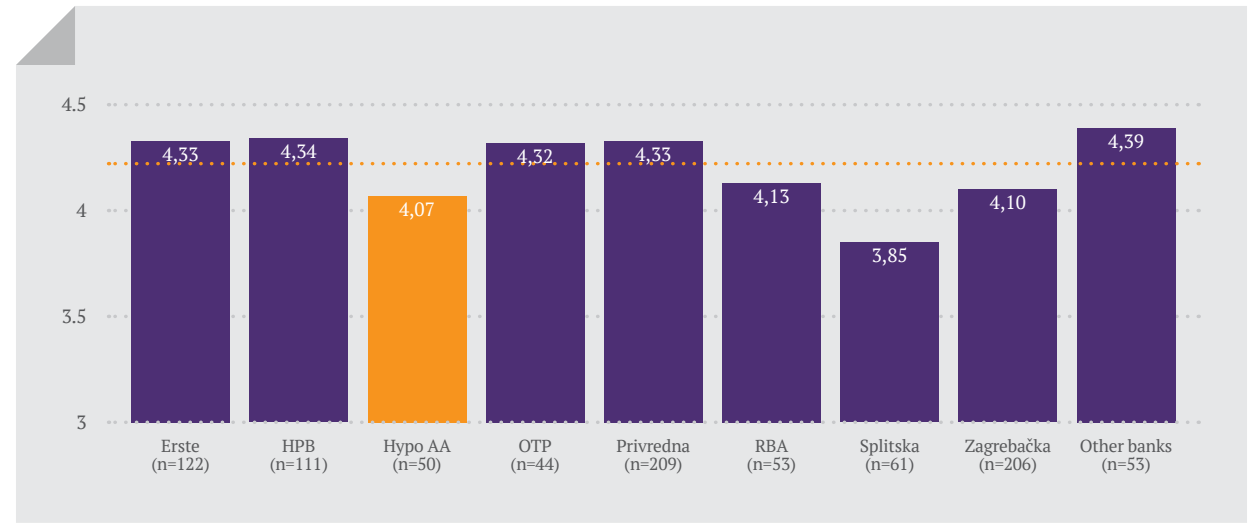

Figure 1. Satisfaction with main bank

The same trend was evident when rating the 'Trust in bank' factor, with Hypo AlpeAdria-Bank's index of 3.84 lower than the banking industry average (3.95). Even though the trustworthiness and reliability factor of the whole banking industry decreased in relation to the previous years, Hypo was still one of the three banks that, at that time, had the highest percentage of respondents who would definitely not recommend the Bank to their friends, as well as the highest percentage of those who would leave the Bank.

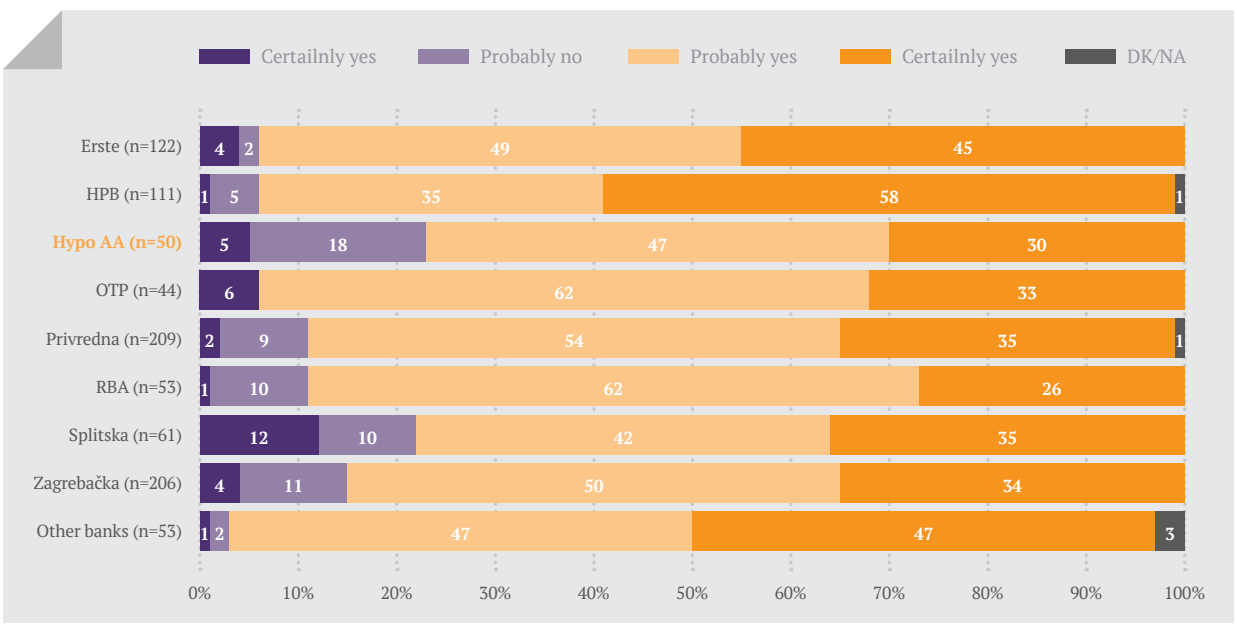

Figure 2. Readiness to recommend the Bank 


\subsection{Internal and External Research and Workshops}

The internal research was done on 20 participants and the sample consisted of Management Board members, executive directors, business development managers, corporate and SME financial advisers, branch managers, sellers and tellers, as well as call centre employees. External research was also conducted on 20 participants. The sample was representative in terms of age and region, and consisted of representatives of each banking sector: regular retail clients, retail VIP clients, corporate and SME clients. The methodology that was used for both internal and external research was in-depth interview.

Also, workshops with management were conducted in order to not only see what the perception of the respondents of the financial industry was, but also to pinpoint Hypo's perception at that particular stage, and also to define what the key factors that needed to be improved and changed were. The conclusion of the workshops and interviews was that new, higher business standards, as well as more efficient banking operations needed to be introduced and implemented, with both the employees and customers being in favour of a more focused and efficient approach with service quality in the foreground rather than a too broad product/service portfolio that was a "nice to have", but that essentially did not correspond with customer needs.

The Bank defined a new business strategy, primarily in the Retail and SME segments, with brand positioning seen as a crucial part of it. After analysing the results of the internal external research, it was clear that a completely new bank needed to be built. It was necessary to move away from an undesirable perception of the past, and increase consumer considerations when choosing a bank, which in the end should lead to building trust and generating business growth in key business segments.

The findings of the research also showed that consumers view non-transparency and complicated communications as an essential feature of banking. This proved to be a valued insight for Addiko that strategically and through all integrated marketing communication activities started the rebranding with directly and indirectly addressing the issue by stating how we see what banking can and should be and what a bank needs to provide customers relevant, credible, tangible and straightforward service. This was confirmed on a continuous basis through senior management statements in the media in the form of Addiko Bank Croatia CEO Mario Žižek’s interview titled “By changing its name and way of doing business, Hypo 
will make a clean start” (Wiesner Mijić, 2016, pp. 18-19) for Croatia’s Večernji list, and Addiko Group's CMO-Corporate/SME Csongor Nemeth's opinion piece titled “Straightforward is the future of banking” published in Croatia's edition of Forbes in June 2016.

Based on the findings of the research the Bank also started a creative teaser campaign named "Mornings of Banking Poetry" where the attention was put on to the problems the consumers pointed out they want from a bank, and the consumers were invited to express their views and frustrations on the "Mornings of Banking Poetry" Facebook page, which was not in any way connected to the Bank. This generated substantial public interest, and social media engagement, and also enabled the Bank to incorporate the valuable insight and feedback into upcoming creative and communications activities on all platforms.

\subsection{Focus Groups}

In order to test the hypothesis about straightforward banking, relevant, credible and tangible services, focus groups were conducted. Research was conducted in Zagreb, with a total of 16 respondents divided in two focus groups (first group aged 25-35; second 36-50). Respondents were customers of various banks who used more than one product or services and that had activated at least one product during the last 12 months.

The research showed that customers appreciate any effort directed towards reducing the complexity of banking services, and according to Ipsos (2016) data, Addiko's straightforward banking concept was generally met with approval, as the tested "Reasons to believe" scored very well with clients, especially the ones showed in the table below:
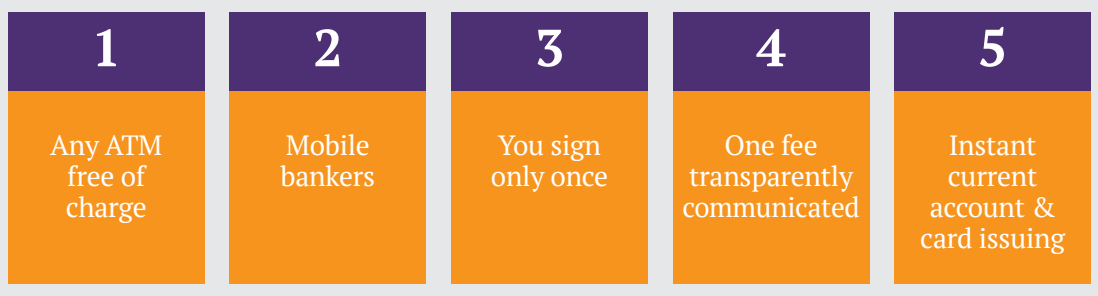

Figure 3. Top five customer "Reasons to believe" score 


\subsection{Brand perception tracking}

Brand tracking research was done via an online research method on the representative sample of Bank customers ages 25-65. Customers were representative in terms of age, gender and region criteria, and the research was conducted on a sample of 500 respondents. The fieldwork was conducted in three waves: October 2016, February 2017 and May 2017.

The research showed that Addiko had a good awareness level but also that it was rising significantly with each research wave. Its position on the market was also significantly better than the position of former Hypo Alpe-Adria-Bank and the desirable difference between the two was growing with each research wave in a favour of Addiko. Prompted and spontaneous awareness level of Addiko Bank was not only good but also significantly improving with each research wave, and it was on the same level as the prompted awareness of some of the largest banks that were present in the Croatian market for a long time.

\subsection{Main Indicators of Brand Development}

\subsubsection{Spontaneous and Prompted Awareness}

As seen in the figure below, almost $60 \%$ of the bank's customers in Croatia were spontaneously aware of Addiko Bank, with its position, in less than a year following the rebranding, which is significantly better than the position of Hypo Alpe-Adria-Bank which was on the Croatian market for more than 20 years. Figure 4 shows the categorized answers of interviewees who were asked to write down which bank first comes to mind, with the possibility of noting all the banks that come to mind. 


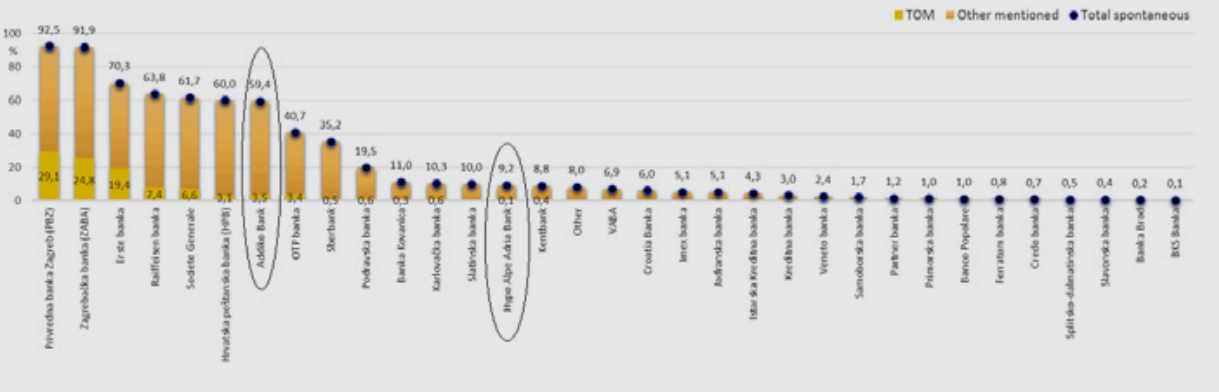

Figure 4. Spontaneous bank awareness

The significant rise of Addiko Bank's spontaneous awareness is visible in comparison to each research wave, while the awareness of Hypo Alpe-Adria-Bank decreased with each research wave.

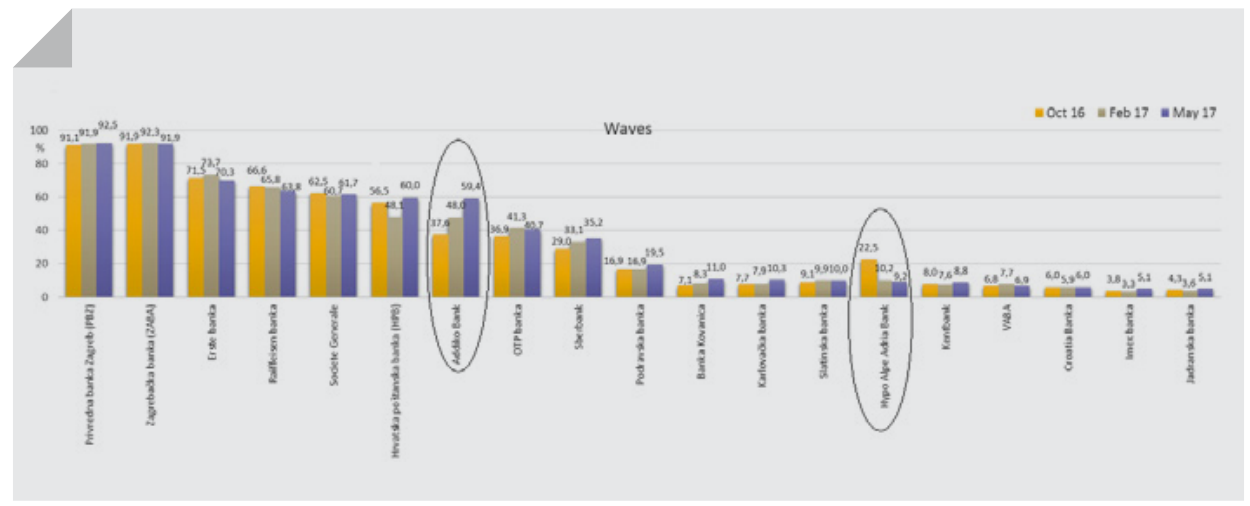

Figure 5. Spontaneous bank awareness per research wave 
In May 2017, after the third wave research results were analysed, Addiko was recognized by 93\% of Croatia's banking population and was included in the group of leading banks on the prompted awareness level, with the Bank's brand recognition significantly growing since the first research wave in October 2016. Such a very high prompted awareness score is, for a new bank without, as previously mentioned, the backing of an international banking group and a completely new name in banking, a very good result.

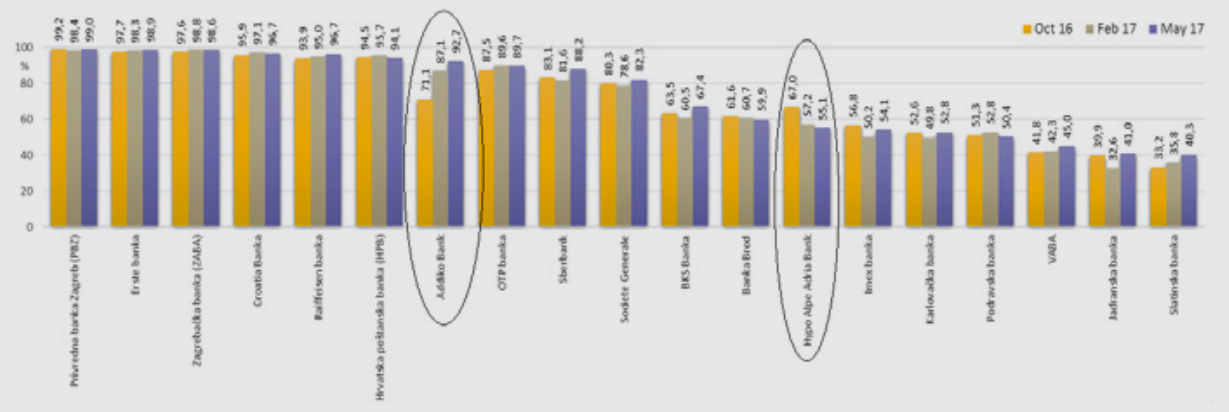

Figure 6. Prompted bank awareness

\subsection{2. “Graveyard” Analysis}

Hendal, one of the leading independent marketing research agencies, was asked to conduct its "Graveyard" analysis, which compares the recall-recognition ratio between the Bank's and the competitors' brands. "The dynamics of brand movement in the graveyard zone is a predictor of future brand health.” (Hendal Report, 2017) The analysis showed that Addiko is positioned on the standard brand awareness path, which suggests that this brand health indicator is good. 


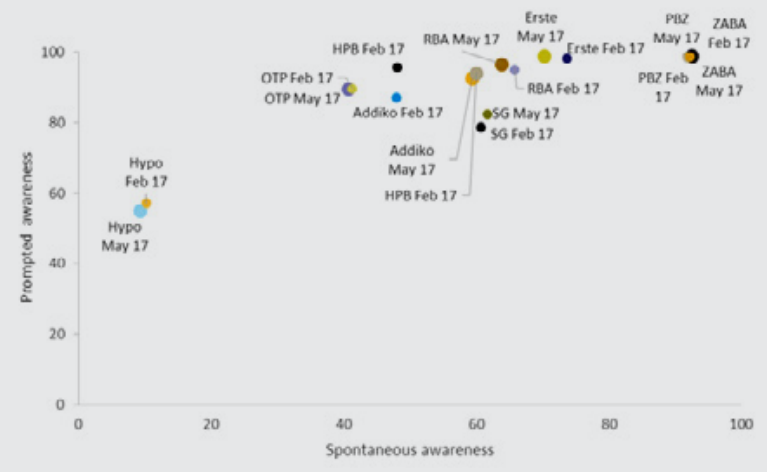

Figure 7. Graveyard analysis by Hendal Market Research

\subsubsection{Consideration}

Even though Addiko has a lower consideration than of some of its competitors, the number of respondents who would consider banking with Addiko as their main bank is growing with each research wave, and significantly exceeds the Bank's market share, which according to the Croatian National Bank data on December 31, 2016 was in terms of total assets at 5.35\%, and on March 31, 2017 at 5.35\%. Also, when looking at the figure below, the authors conclude that rebranding had a positive impact on the Bank's perception since consideration after rebranding grew by more than $200 \%$.

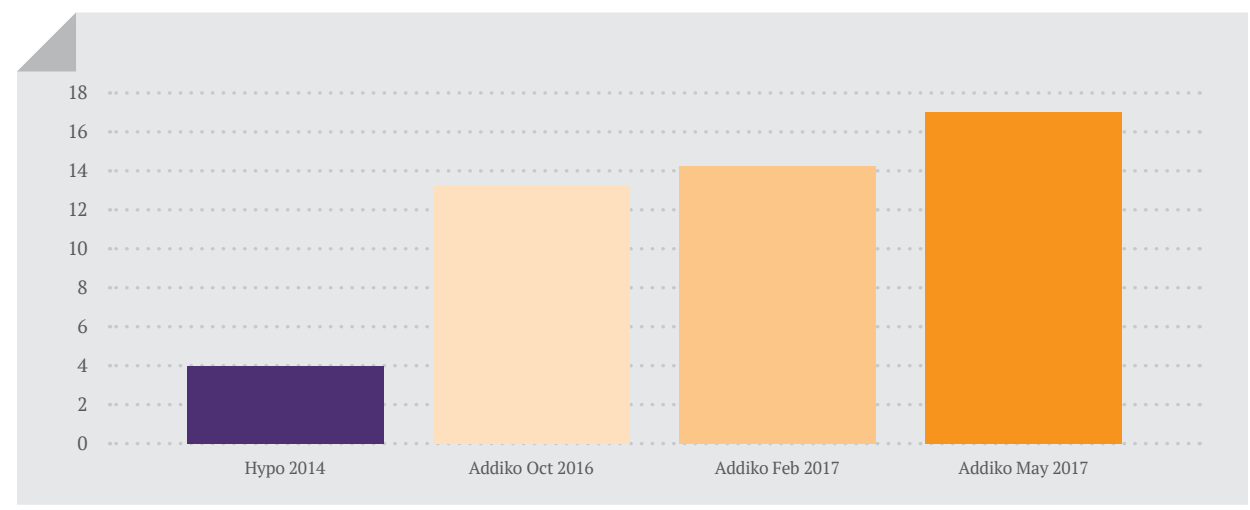

Figure 8. Consideration of Addiko as the main bank per research wave 


\subsubsection{The Switching Intention}

Switching intention of current customers was also one of the elements that was considered in this research. It showed how likely clients would switch from one bank to another. Since Addiko inherited Hypo's clients, the number of "switchers" was very high in 2016. However, in comparison to the first research wave, the share of Addiko "switchers" decreased considerably, down by as much as $15 \%$ in the October 2016 - May 2017 period. At the same time, even though switching willingness on the industry level is increasing (up $0.8 \%$ between the research waves), for Addiko, this is not the case. At the same time, Addiko has attracted $37 \%$ of "switchers".

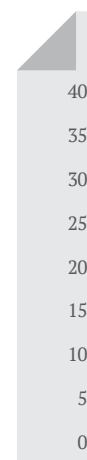

October 2016

February 2017

May 2017

Figure 9. Intention of Addiko customers to change banks

\subsubsection{Straightforward Banking Principles to Support Brand and Reputation}

Addiko's driving idea during rebranding was the delivery of straightforward banking, which according to the Bank, stands for: focus on essentials, delivering on efficiency and communicating simply. These brand values were supposed to be promises the Bank made to the customers in the rebranding process and hence drive not only consideration and purchase willingness but also reputation. An increase of positive associations with such attributes is seen in the research, indicating that customer perception of Addiko's straightforward banking attributes is growing. 
Fast services

Transparent

in offers

Simple services

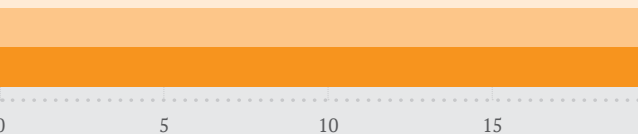

10

15

20

25

Figure 10. Perception of Addiko's straightforward banking attributes

\section{Acknowledgements and Limitations}

The general limitations of the research are in the size of the sample in the brand tracking research. Even though 500 respondents form a good and representative sample, when taking into consideration that Addiko has a 5\% market share, the representative sample for Addiko customers was in reality small. Also, the fact that satisfied customers were mainly the ones interested in sharing their attitudes on the Bank and participating in the research can be considered a limitation of the research. This is also the case for the short tracking period, with ten months being too short a time for building a reputation and drawing undisputable conclusions. An additional limitation the researchers faced was the lack of comparable data in the years prior to rebranding. Although, additional research over a longer period of time is required to provide a broader picture, the authors nevertheless believe that the research provides concrete and useful academic and practical data on repositioning, rebranding and reputation management. 


\section{Conclusion}

Even though each rebranding process brings up general, as well as specific challenges, with the Addiko Bank example not being any different, the Bank's rebranding proved to be successful both from the business, image and reputation standpoint. Hypo Alpe-Adria-Bank, primarily due to its tarnished image as a result of its legacy, was not only losing clients in the period prior to the new ownership taking over, but also had a very low consideration level for doing business by the public.

Changing not only the brand name and colours, but the business strategy and focusing on banking essentials, with straightforward banking in mind, Addiko in only one year managed to make a huge impact in the Croatian market. Not only did brand recognition (awareness and spontaneous) grow, but this was also followed step-by-step with growth of consideration, positive attributes, perception of straightforward banking, which resulted in an improved image along with the growth of key business segments, with retail disbursements up 110\% and Corporate/SME up 75\% in 2016 in comparison to 2015, with the Bank recording a positive year-end result (the best in the last four years) following an industry record loss in 2015, with the positive trends also continuing in 2017 (Milovan, 2017, para 3-4).

Taking into account the report for SEE consumer habits (Kearney, 2013) that concluded that the Bank's customers in Croatia rank the most influential factors for choosing a bank in the following order: (a) reputation/trust; (b) availability; (c) product price; (d) quality of service, it can be concluded that Addiko made significant progress in the aforementioned most important criteria - reputation. On the "soft" side of reputation, Addiko was named as one of the nine most beautiful brand identities in banking by The Financial Brand (Pilcher, 2016), while in the competition of over 12,700 searches on Google.hr, Addiko had three terms "Addiko", "Addiko Bank" and "Addiko banka", among the 250 top yearly searches in Croatia and this in only 6 months after the new brand was launched. On the first anniversary of the first brand, on 11 July 2017, following an in-depth analysis by ICERTIAS-International Certification Association that analyses an organization's reputation, user experience, communication and trust factor, Addiko Bank was awarded the certificate of excellence, and thus became the first bank in Croatia with this international recognition (Addiko, July 2017). 


\section{Reference List}

- Balmer, J. M. T., Gray, E. R. (1999). Corporate identity and corporate communications. Corporate Communications: An International Journal, 4 (4), 171-176.

- Balmer, J. M. T., Grayser, S. A. (2003). Revealing the Corporation Perspectives on identity, image, reputation, corporate branding, and corporate-level marketing. London, New York: Routledge.

- Clifton, R. (2009). Brands and branding (Economist Books). London: Bloomberg Press.

- Fog, K., Budtz, C., Munch, P., Blanchette, S. (2001). Storytelling: Branding in Practice. Dordrecht, Heidelberg, London, New York: Springer.

- Fombrun, C. J., Rindova, V. (1996). Who's Tops and Who Decides? The Social Construction of Corporate Reputations. New York University: School of Business Working Paper.

- Fombrun, C. J., van Riel, C. B. M. (1998). The Reputational Landscape. Corporate Reputation Review, 1 (1), 5-13.

- Hatch, M. J., Schultz, M. (2008). Taking Brand Initiative: How companies can align strategy, culture and identity through corporate branding. San Francisco: Jossey-Bass.

- Ind, N. (2003). Beyond Branding. London, Sterling, VA: Kogan Page Limited.

- Light, L., Kiddon, J. (2016). Six Rules of Brand Revitalization: Learn the Most Common Branding Mistakes and How to Avoid Them. New Jersey: Pearson Education.

- Margulies, W. (1977). Make the most of your corporate identity. Harvard Business Review, 66-77.

- Mattone, J., Vaidya, N. (2016). Cultural transformations: Lessons of leadership \& corporate reinvention from the C-suite elite. New Jersey: Wiley.

- Murphy, J. M. (Ed.) (1987). Branding: A Key Marketing. Basingstoke: Macmillan.

- Roberts, J. (2004). The modern firm: organizational design for performance and growth. New York: Oxford University Press.

- Siegert, G., Förster, K., Chan-Olmsted, S. M., Ots, M. (Eds.) (2015). Handbook of Media. Dordrecht, Heidelberg, London, New York: Springer.

\section{Other References}

- Addiko Bank, Press releases (2017). Addiko Bank wins international “Customer's Friend” certificate. Retrieved from: https://www. addiko.hr/o-nama/press-i-publikacije/priopcenja-za-javnost/. 12 July 2017.

- A. T. Kearney Report (2013). SEE Personal and Consumer Habits.

- Croatian National Bank (2016, February). Unrevised and unconsolidated banking industry data for Y2016. Retrieved from: http:// www.hnb.hr/statistika/statisticki-podaci/kreditne-institucije/pokazatelji-poslovanja-kreditnih-institucija. 26 April 2017.

- Croatian National Bank (2017, May). Unrevised and unconsolidated banking industry data for first quarter 2017. Retrieved from: http://www.hnb.hr/statistika/statisticki-podaci/kreditne-institucije/pokazatelji-poslovanja-kreditnih-institucija. 18 May 2017.

- Dixon-James (2015, 19 May). Fueling Growth and Brand Irrelevancy - The Leading Reasons for Company Rebranding. Retrieved from: http://www.dixon-james.com/fueling-growth-and-brand-irrelevancy-the-leading-reasons-for-company-rebranding/. $5 \mathrm{May} 2017$.

- GfK (2014). Financial Market Data Survey.

- Gruber,A., \& Nasralla, S. (2015, 7 July). Decline and fall of Hypo Alpe Adria, symbol of Austria's Balkan ambitions, Reuters. Retrieved from: http://www.reuters.com/article/us-austria-heta-factbox-idUSKCNOPH1FQ20150707.15 May 2017.

- Hendal (2017, May). Market research - Graveyard analysis.

- Ipsos (2016). News Positioning and Evaluation of the RTB's customer research.

- Milovan, A. (2017, 4 May). Retail lending up 110 percent. Jutarnji list, pp 20-21.

- Munteanu, R. (2016, 15 May). We are building a new bank on the foundation of a new brand.Lider magazine's special supplement "Brands", p. 14.

- Nemeth, C. (2016, 1 June). Straightforward is the future of banking. Forbes, pp 79.

- Pilcher, J. (2016, 14 November). Nine of the most beautiful brand identities in banking. The Financial Brand. Retrieved from: https://thefinancialbrand.com/62182/9-best-bank-brand-identities/. 16 November 2017.

- Steinhauser, G. (2014, 28 August). Hypo Alpe-Adria-Bank Mess. Wall Street Journal. Retrieved from: http://blogs.wsj.com/ briefly/2014/08/28/the-hypo-alpe-adria-bank-mess-at-a-glance/. 15 May 2017.

- Wiesner Mijić, V. (2016, 13 June). By changing its name and way of doing business, Hypo will make a clean start. Večernji list, pp 18-19. 


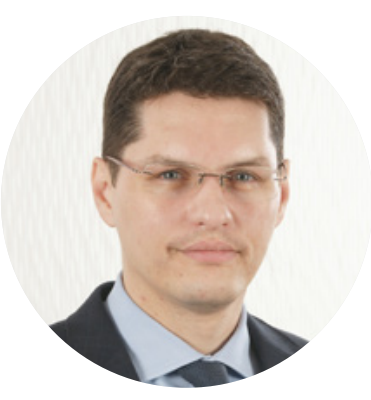

\section{Igor Vukasović}

Igor Vukasović has been the Corporate Communications Director/Manager of Addiko Bank Croatia (former Hypo Alpe-Adria-Bank) since 2011. During 2015/2016 he also had an extended role, and as Head of the Group Corporate Communications oversaw the communication operations in Croatia, Slovenia, Serbia, Bosnia-Herzegovina, Monte Negro and Austria, and was in charge of the communication aspect of the Group's privatization and rebranding. He started his career in PR in early 2000s after graduating Journalism at Faculty of Political Science (FPZ), University of Zagreb, and is currently undergoing a $\mathrm{PhD}$ program Information and Communication Sciences. He completed an "Integrated Approach to Public Relations” program from LSPR and a business excellence program from IEDC BLED. Since 2009 he has been a permanent guest lecturer at FPZ's, and as of 2014 he is a professor at Edward Bernays College of Communication Management. Igor is a published author of several academic papers and articles dealing with the topics of corporate and crisis communications, brand, reputation and destination management.

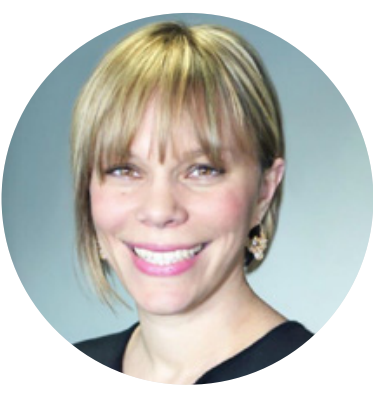

\section{Iva Ančić}

Iva Ančić graduated Management in Tourism at the Rochester Institute of Technology, Croatia. She spent six years working in tourism industry, mainly in USA and Ireland. After returning to Croatia she started her career in marketing working on projects varying from campaign and event management, market research to rebranding. In 2012 she got her Masters degree in Marketing Communications at the Faculty of Economic and Business, University of Zagreb and is currently undergoing a $\mathrm{PhD}$ program International Relations at University of Zadar and DIU International University. She is an external associate at Edward Bernays College and her points of interest are marketing, advertising, communication and tourism.

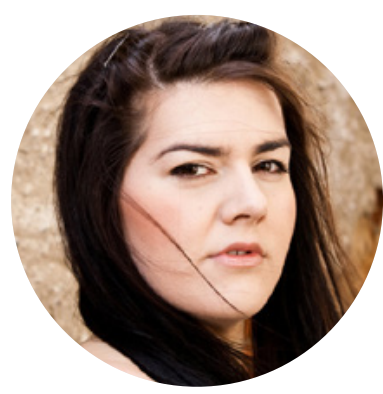

\section{Dora Starčević}

Dora is currently finishing masters degree study at Edward Bernays College of Communication Management (Course: Public Relations). She obtained bachelor degree at University of Applied Sciences Baltazar Zaprešić in field of cultural management. In the past five years lived and worked abroad (Chicago, USA and Vienna, Austria). Employed at website Muzika.hr as a PR and Office Manager. Also been hired at a position Assistant Project Director for three years in a row at REXPO - international fair for investment projects. Business interests: Public Relations, Event management, Influencer Marketing, Human Resources, Culture and Tourism. 